This item was submitted to Loughborough's Research Repository by the author.

Items in Figshare are protected by copyright, with all rights reserved, unless otherwise indicated.

\title{
A fuel cell system sizing tool based on current production aircraft
}

PLEASE CITE THE PUBLISHED VERSION

https://doi.org/10.4271/2017-01-2135

\section{PUBLISHER}

(C) SAE International

\section{VERSION}

AM (Accepted Manuscript)

\section{PUBLISHER STATEMENT}

This work is made available according to the conditions of the Creative Commons Attribution-NonCommercialNoDerivatives 4.0 International (CC BY-NC-ND 4.0) licence. Full details of this licence are available at: https://creativecommons.org/licenses/by-nc-nd/4.0/

\section{LICENCE}

CC BY-NC-ND 4.0

\section{REPOSITORY RECORD}

Thirkell, Alex, Rui Chen, and lan Harrington. 2017. "A Fuel Cell System Sizing Tool Based on Current Production Aircraft”. figshare. https://hdl.handle.net/2134/27634. 


\title{
A Fuel Cell System Sizing Tool based on Current Production Aircraft
}

\author{
Author, co-author (Do NOT enter this information. It will be pulled from participant tab in \\ MyTechZone) \\ Affiliation (Do NOT enter this information. It will be pulled from participant tab in MyTechZone)
}

\begin{abstract}
Electrification of aircraft is on track to be a future key design principal due to the increasing pressure on the aviation industry to significantly reduce harmful emissions by 2050 and the increased use of electrical equipment. This has led to an increased focus on the research and development of alternative power sources for aircraft, including fuel cells. These alternative power sources could either be used to provide propulsive power or as an Auxiliary Power Unit (APU). Previous studies have considered isolated design cases where a fuel cell system was tailored for their specific application. To accommodate for the large variation between aircraft, this study covers the design of an empirical model, which will be used to size a fuel cell system for any given aircraft based on basic design parameters. The model was constructed utilising aircraft categorisation, fuel cell sizing and balance of plant sub-models. Fifteen aircraft categories were defined based on the primary function and propulsion method of the aircraft. For each category, propulsive power and electrical generation requirements were calculated. Based on the results from categorisation and the flight envelope of the aircraft, fuel cell and balance of plant systems are defined. The total system mass and volume are given as outputs, along with polarisation and power curves for the fuel cell. This study finds that the model can accurately predict the electrical generation capability and propulsive requirements across the defined aircraft categories. In addition, the model can appropriately define key, high-level fuel cell parameters based on current Polymer Electrolyte Membrane (PEM) technology. Total fuel cell system mass and volume are calculated and shown to be reasonable for small aircraft. For larger aircraft with a Maximum Take-Off Weight (MTOW) greater than $50,000 \mathrm{~kg}$, current PEM technology is not able to match the gravimetric power density of existing APUs.
\end{abstract}

\section{Introduction}

Electrification of aircraft is on track to be a key design principal in the future due to the increasing pressure on the whole aviation industry to significantly reduce harmful emissions by 2050 [1]. This has led to an increased focus on the research and development of alternative power sources for aircraft, including fuel cells. These alternative power sources could either be used to provide propulsive power or as an Auxiliary Power Unit (APU).

Hydrogen fuel cells produce electricity through an exothermic electrochemical reaction between hydrogen and oxygen. This highly efficient reaction only produces heat and water as by-products [2].

Two Fuel Cell (FC) technologies currently being researched for use

Page 1 of 11 in aerospace applications are Solid Oxide Fuel Cells (SOFC) and Polymer Electrolyte Membrane (PEM) fuel cells. A key difference between these two technologies is their operating temperature. The significantly higher operating temperature of a SOFC $\left(700-1,000^{\circ} \mathrm{C}\right)$ compared with $60-100^{\circ} \mathrm{C}$ for a PEM FC [3] allows it to reform light fossil fuels such as methane into hydrogen. However, if PEM fuel cells are used, then their relatively low operating temperature could potentially reduce the thermal signature of the electrical generation and/or propulsive system of the aircraft.

Several studies have previously considered the integration of fuel cell systems into aircraft [4-18]. Different aspects of the integration process have been considered. These included the theoretical integration of a FC system to partially cover the electrical load on the APU on a Boeing 787-8 [14]. In addition, working prototypes on a small remote piloted scale have been designed and flown [4-6, 9-11]. The success of these studies has ranged from flights of three minutes to over two hours on FC power.

Each previous study looked at their aircraft as an isolated design case and tailored the FC system for their specific application. As there are a large range of airframe types, each suited to a particular mission profile, there will be a wide range of performance requirements placed on the FC system. To accommodate this large variation, this paper will cover the design of an empirical model, which will be designed to size a PEM FC system for any given aircraft based on basic design parameters.

This paper aims to develop a method of predicting aircraft electrical generation capability and propulsive requirements. A model to size a PEM FC system for any aircraft as either a propulsive power provider or APU will also be developed. This will be designed as a guide for aircraft Original Equipment Manufacturers (OEM).

\section{Methodology}

Empirical modelling work was split into three main sections: aircraft categorisation, fuel cell modelling and balance of plant calculations. These were then combined to make the full model.

\section{Aircraft Categorisation}

Data for 527 aircraft were collected for categorisation [19-29]. Aircraft were categorised using a two-step method. Initially, 11 categories were defined based on an aircraft's primary role and easily distinguishable physical characteristics. These categories are summarised in Table 1. Each category was further subdivided based 
on its propulsion method into those propelled by a propeller and those propelled by a jet derived engine. This gave a total of 15 subcategories for the model to be based on.

Table 1. Aircraft category definitions

\begin{tabular}{|c|c|}
\hline Aircraft category & Key characteristics \\
\hline Fuel cell & $\begin{array}{l}\text { Primary power source must be a Fuel Cell (FC). The } \\
\text { aircraft can be either manned or unmanned. }\end{array}$ \\
\hline All electric & $\begin{array}{l}\text { Propulsion must be provided by an electric motor } \\
\text { and electricity must not be supplied by a fuel cell. }\end{array}$ \\
\hline Unmanned & $\begin{array}{l}\text { Any fixed wing aircraft which is either remotely } \\
\text { piloted or autonomously controlled and is neither } \\
\text { 'all electric' or powered by a fuel cell. }\end{array}$ \\
\hline $\begin{array}{l}\text { Bomber and } \\
\text { surveillance }\end{array}$ & $\begin{array}{l}\text { Aircraft designed for the primary role of dropping } \\
\text { ordinance or performing surveillance. }\end{array}$ \\
\hline Fighter and trainer & $\begin{array}{l}\text { A manned aircraft with a primary role as a military } \\
\text { fighter or trainer. These aircraft typically have a } \\
\text { high thrust to weight ratio. }\end{array}$ \\
\hline Transport & $\begin{array}{l}\text { Typically, a military aircraft for transporting } \\
\text { personnel. Aircraft in this category generally have } \\
\text { Maximum Take-Off Weight (MTOW) greater than } \\
\text { 100,000kg. }\end{array}$ \\
\hline Airliner and freighter & Typically, large multiengine aircraft. \\
\hline Business & $\begin{array}{l}\text { An aircraft typically designed for transporting small } \\
\text { groups of people. This category also includes } \\
\text { privatised versions of larger aircraft. }\end{array}$ \\
\hline Utility & $\begin{array}{l}\text { Typically, a small general-purpose aircraft for } \\
\text { transporting people or freight. }\end{array}$ \\
\hline Amphibian & $\begin{array}{l}\text { More specialised aircraft designed to take-off from } \\
\text { and land on water. }\end{array}$ \\
\hline Lightplane & $\begin{array}{l}\text { Any aircraft that does not fit into another category } \\
\text { and has a MTOW less than } 3500 \mathrm{~kg} \text {. }\end{array}$ \\
\hline
\end{tabular}

For each sub-category, the Maximum Take-Off Weight (MTOW) was related to either the propulsive power or maximum thrust produced by the aircraft. This provided a good correlation as expected from the form of the standard aircraft power and thrust equations which directly relate the power or thrust required to aircraft weight [30].

Changes in MTOW were also found to correlate well with the electrical generation capability of each of the aircraft. The electrical generation capability of an aircraft was defined as the total capacity of all engine mounted generators as well as any capability provided by an APU.

Each relationship was refined systematically by curve fitting the model results with the raw aircraft data using the least squares method. When considering trendline options in Excel, the focus was on linear and polynomial types as exponential and power lines lead to an inaccurate coefficient of determination $\left(R^{2}\right)$ [31]. When considering the regression analysis carried out by Excel, $\mathrm{R}^{2}$ can have a value between zero and one. The larger the value of $\mathrm{R}^{2}$ the smaller the residual sum of squares and therefore the better fit the trendline is to the data [32].

Figure 1 shows an example of the refined relationships for existing FC powered aircraft. All the aircraft used in the construction of this chart were propelled by a propeller attached to an electric motor.

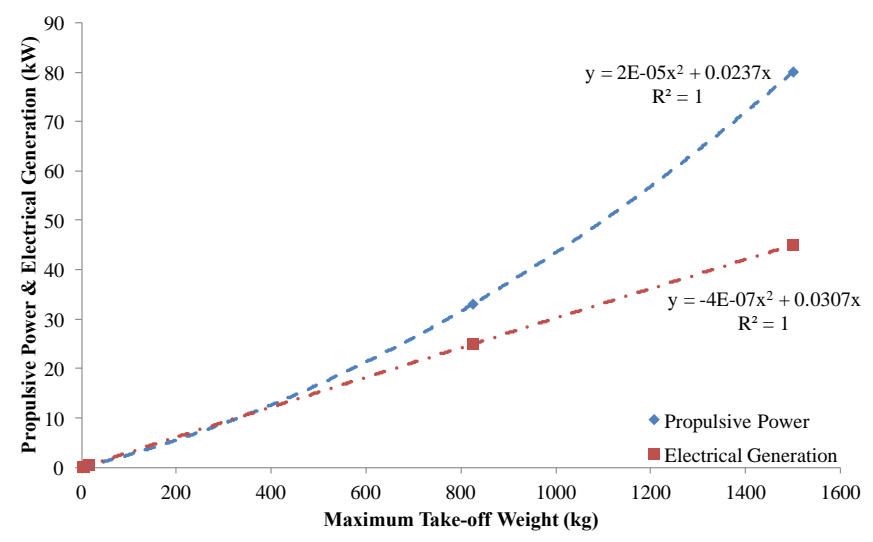

Figure 1. Refined correlations for existing fuel cell powered aircraft

\section{Fuel Cell Sizing Model}

A simplified FC model was used to find the fuel and oxidant requirements as well as an estimated mass and volume for the stack. Fuel, in this case hydrogen $\left(\mathrm{H}_{2}\right)$ usage was found using Equation 1 [33]. Scaling factors, shown in Table 2 were used to set the FC power $\left(\mathrm{P}_{\text {elec}}\right)$ higher than the output from the aircraft model. This was done to allow for degradation of the FC over time as well as increased flexibility for peak loads.

$\dot{m}_{H_{2}}=\frac{M_{H_{2}} P_{\text {elec }} \lambda}{2 V_{c} F}$

Where,

$\dot{m}_{H_{2}}=$ hydrogen mass flow rate required by the stack $(\mathrm{kg} / \mathrm{s})$

$M_{\mathrm{H}_{2}}=$ molar mass of hydrogen $(2.016 \mathrm{~g} / \mathrm{mol}$ [34])

$\mathrm{P}_{\text {elec }}=$ fuel cell electrical power request $(\mathrm{W})$

$\lambda=$ stoichiometric ratio

$\mathrm{V}_{\mathrm{c}}=$ average cell voltage $(\mathrm{V})$

$\mathrm{F}=$ Faraday constant $(96,485 \mathrm{C} / \mathrm{mol}[30])$

Table 2. Fuel cell power scaling factors

\begin{tabular}{|l|l|}
\hline Fuel cell purpose & Scaling factor \\
\hline Propulsive power & $P_{\text {elec }}=1.5 P_{\text {aircraft model }}$ \\
\hline APU & $P_{\text {elec }}=1.2 P_{\text {aircraft model }}$ \\
\hline
\end{tabular}

Fuel cells can either be of an air breathing or air independent design. Oxidant usage, in the form Oxygen $\left(\mathrm{O}_{2}\right)$ either from air or from onboard $\mathrm{O}_{2}$ storage was calculated using Equation 2 [33].

$\dot{m}_{\mathrm{O}_{2}}=\frac{M_{\mathrm{O}_{2}} P_{\text {elec }} \lambda}{4 V_{c} F}$ 
Where,

$\dot{m}_{\mathrm{O}_{2}}=$ oxygen mass flow rate required by the stack $(\mathrm{kg} / \mathrm{s})$

$M_{\mathrm{O}_{2}}=$ molar mass of hydrogen $(31.998 \mathrm{~g} / \mathrm{mol}$ [35])

$\mathrm{P}_{\text {elec }}=$ fuel cell electrical power request $(\mathrm{W})$

$\lambda=$ stoichiometric ratio

$\mathrm{V}_{\mathrm{c}}=$ average cell voltage $(\mathrm{V})$

$\mathrm{F}=$ Faraday constant $(96,485 \mathrm{C} / \mathrm{mol}[30])$

Current commercial FC stacks fall into two main categories based on the cooling method used: Air-Cooled (AC) and Liquid-Cooled (LC). Generally, air cooling is used when the gross stack power is $\leq 5 \mathrm{~kW}$ [36]. Due to the inherent design differences between the two cooling options, both stack designs have different gravimetric and volumetric power densities. Existing commercial stack data from Ballard, Horizon Energy Systems, Hydrogenics, Intelligent Energy and Pragma [36-46] was used to find average parameters, Table 3.

Table 3. Average power densities from commercial PEM FC stack data [3646]

\begin{tabular}{|l|l|l|}
\hline $\begin{array}{l}\text { Cooling } \\
\text { option }\end{array}$ & $\begin{array}{l}\text { Average gravimetric power } \\
\text { density }(\mathbf{k W} / \mathbf{k g})\end{array}$ & $\begin{array}{l}\text { Average volumetric power } \\
\text { density }(\mathbf{k W} / \text { litre })\end{array}$ \\
\hline AC & 0.303 & 0.189 \\
\hline LC & 0.443 & 0.540 \\
\hline
\end{tabular}

The Department of Energy (DOE) has set targets [47] to improve the gravimetric and volumetric power densities of PEM FCs. These are summarised in Table 4.

Table 4. DOE targets for $80 \mathrm{~kW}$ (net) integrated transportation FC power systems operating on direct hydrogen [47]

\begin{tabular}{|l|c|c|}
\cline { 2 - 3 } \multicolumn{1}{c|}{} & $\mathbf{2 0 2 0}$ targets & Ultimate targets \\
\hline Gravimetric power density (kW/kg) & 0.65 & 0.85 \\
\hline Volumetric power density (kW/litre) & 0.65 & 0.85 \\
\hline
\end{tabular}

To provide a visual representation of the modelled FC to the user, data to produce polarisation and power curves was calculated. Equation 3 was used to combine the irreversible voltage losses associated with activation, ohmic resistance and mass transport within the FC of an air-breathing design [48]. Cell voltage was calculated for a range of current densities so that a polarisation curve could be generated.

$V_{c}=E_{0_{H H V}}-\frac{R T}{2 \alpha F} \ln \left(\frac{i+i_{n}}{i_{0}}\right)-i \Omega-m e^{n i}$

Where,

$\mathrm{V}_{\mathrm{c}}=$ average cell voltage $(\mathrm{V})$

$E_{0_{H H V}}=$ thermodynamic reversible voltage based on the higher

heating value (HHV) of hydrogen $(1.23 \mathrm{~V}[33,48-50])$

$\mathrm{R}=$ universal gas constant $(8.314 \mathrm{~J} / \mathrm{molK}[30])$

$\mathrm{T}=$ operating temperature $(323.15 \mathrm{~K}$, low temperature chosen to improve efficiency [50])

$\alpha=$ charge transfer coefficient $(0.5[48,49])$

$\mathrm{F}=$ Faraday constant $(96,485 \mathrm{C} / \mathrm{mol}[30])$

$\mathrm{i}=$ current density $\left(\mathrm{A} / \mathrm{cm}^{2}\right)$

Page 3 of 11 $\mathrm{i}_{\mathrm{n}}=$ internal and fuel crossover equivalent current density

$\left(0.002 \mathrm{~A} / \mathrm{cm}^{2}[33,50]\right)$

$\mathrm{i}_{0}=$ exchange current density $\left(3.0 \times 10^{-6} \mathrm{~A} / \mathrm{cm}^{2}[50]\right)$

$\Omega=$ ohmic resistance $\left(0.245 \Omega \mathrm{cm}^{2}[49]\right)$

$\mathrm{m}=$ mass transport loss empirical constant $1\left(3.0 \times 10^{-5} \mathrm{~V}\right.$ [49])

$\mathrm{n}=$ mass transport loss empirical constant $2\left(7 \mathrm{~cm}^{2} / \mathrm{A}\right.$ similar to [49])

The relationship between reactant partial pressures and FC performance is described by the Nernst equation [33, 48-50] shown in Equation 4. If the $\mathrm{FC}$ is supplied with pure $\mathrm{O}_{2}$ instead of air, the performance will improve as the partial pressure of $\mathrm{O}_{2}$ will increase.

$V_{c}=E_{0_{H H V}}+\frac{R T}{2 F} \ln \left(\frac{P_{H_{2}} \cdot P_{O_{2}}^{\frac{1}{2}}}{P_{H_{2} O}}\right)$

Where,

$\mathrm{V}_{\mathrm{c}}=$ average cell voltage $(\mathrm{V})$

$E_{0_{H H V}}=$ thermodynamic reversible voltage based on the HHV of hydrogen $(1.23 \mathrm{~V}[33,48-50])$

$\mathrm{R}=$ universal gas constant $(8.314 \mathrm{~J} / \mathrm{molK}[30])$

$\mathrm{T}=$ operating temperature $(323.15 \mathrm{~K}$, low temperature chosen to improve efficiency [50])

$\mathrm{F}=$ Faraday constant $(96,485 \mathrm{C} / \mathrm{mol}[30])$

$P_{\mathrm{H}_{2}}=$ partial pressure of hydrogen $(\mathrm{Pa})$

$P_{\mathrm{O}_{2}}=$ partial pressure of oxygen $(\mathrm{Pa})$

$P_{\mathrm{H}_{2} \mathrm{O}}=$ partial pressure of water in exhaust $(\mathrm{Pa})$

Given that the molar proportion of air that is $\mathrm{O}_{2}$ is 0.21 [48], the change in cell voltage expected by using pure $\mathrm{O}_{2}$ instead of air is given by Equation 5 [50].

$\Delta V_{c}=\frac{R T}{2 F} \ln \left[\left(\frac{1}{0.21}\right)^{0.5}\right]+\frac{R T}{\alpha F} \ln \left(\frac{1}{0.21}\right)$

Where,

$\mathrm{V}_{\mathrm{c}}=$ average cell voltage $(\mathrm{V})$

$E_{0_{H H V}}=$ thermodynamic reversible voltage based on the HHV of hydrogen $(1.23 \mathrm{~V}[33,48-50])$

$\mathrm{R}=$ universal gas constant $(8.314 \mathrm{~J} / \mathrm{molK}[30])$

$\mathrm{T}=$ operating temperature $(323.15 \mathrm{~K}$, low temperature chosen to improve efficiency [50])

$\mathrm{F}=$ Faraday constant $(96,485 \mathrm{C} / \mathrm{mol}[30])$

$\alpha=$ charge transfer coefficient $(0.5[48,49])$

Using the operating conditions shown above, the change in cell voltage expected by using pure $\mathrm{O} 2$ was calculated to be,

$$
\Delta V_{c}=0.0152 \mathrm{~V}
$$

By defining the desired FC operating point as a target power of $250 \mathrm{~W}$ and an operating cell voltage of $0.6 \mathrm{~V}$ the number of cells in the FC was calculated for both an air breathing and air independent design. These were found to be 42 cells for the air breathing system and 41 cells for the air independent system. Polarisation and power curves were then generated and collated in Figure 2.

Increased performance is represented by the higher average cell voltage on the polarisation curve and higher potential peak power. In addition to the thermodynamic effect of using pure $\mathrm{O}_{2}$ demonstrated by Equation 5, operation with pure $\mathrm{O}_{2}$ usually eliminates the mass transport polarisation also shown in Figure 2. 


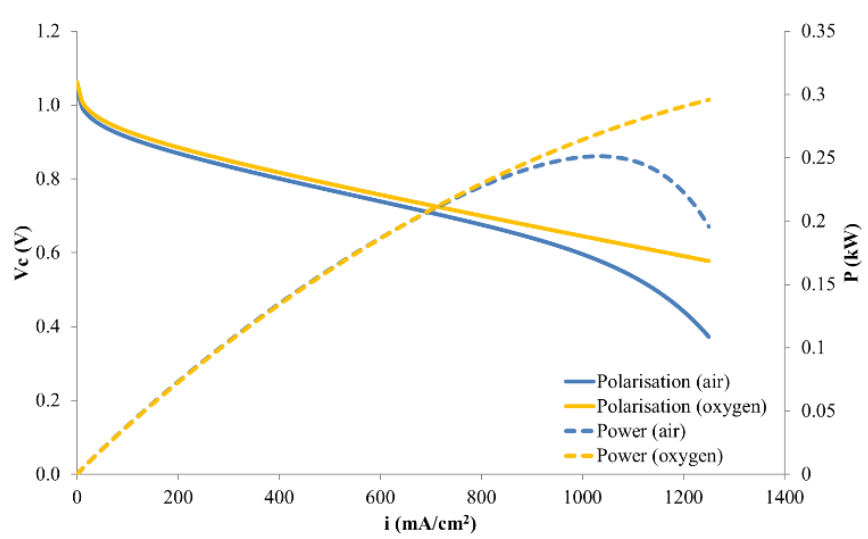

Figure 2. Modelled polarisation and power curves based on desired operating point for air breathing and air independent FC designs

\section{Balance of Plant Model}

In addition to the stack, the other key components in a FC system are collectively referred to as the Balance of Plant (BoP). The cooling and fuelling subsystems are the most significant components of the $\mathrm{BoP}$ in terms of mass and volume. Both will need to be considered when calculating the total mass and volume of the FC system.

\section{Cooling}

Balance of plant components required for Air-Cooled (AC) fuel cells are substantially different to those required for Liquid-Cooled (LC) fuel cells.

For this cooling method, generally a fan is used to provide airflow which is directed across the cells by some form of cowling. To calculate the mass of this subsystem, both the mass of the fan and the cowling must be found. The actual mass of fan required for the desired airflow was found from a relationship derived from commercial fans [51-53].

The volume of the subsystem was found by combining the estimated dimensions of the FC stack with the depth of the subsystem. Fan depth found from a relationship derived from commercial data [5153].

Commercial LC fuel cells are generally accompanied by cooling module designed in-house. A typical LC subsystem may include: working liquid, liquid container, pumps, radiator and a cooling fan. Scaling factors were based on the ratio of FC stack mass and volume to cooling subsystem mass and volume of Ballard FCveloCity-HD systems [45]. These are summarised in Table 5.

Table 5. Liquid-cooling subsystem scaling factors [46]

\begin{tabular}{|l|l|}
\hline LC subsystem mass & $17 \%$ of stack mass \\
\hline LC subsystem volume & $29 \%$ of stack volume \\
\hline
\end{tabular}

The Department of Energy (DOE) has set target of reducing the mass of the air delivery and humidification systems by $23 \%$ by 2020 [47].

\section{Fuel Storage and Delivery}

Both the fuel, generally $\mathrm{H}_{2}$ and an oxidant, generally $\mathrm{O}_{2}$ must be delivered to the FC continuously during flight. The fuel and oxidant can either be stored on-board the aircraft or generated by breaking down water through electrolysis. An electrolyser will require its own power source which will add to the complexity of the system. To avoid this complexity, and the keep the system as light as possible both fuel and oxidant will be stored on the aircraft. Details of how the storage and delivery model was made are given separately for the fuel and oxidant.

\section{Hydrogen}

Hydrogen fuel must be stored on-board the aircraft in a sufficient quantity to meet the desired endurance requirement. In addition, the mass, volume and ease of refuelling are all critical parameters of the fuelling system. Figure 3 shows the gravimetric and volumetric storage densities of various hydrogen storage options. As aerospace applications tend to be more mass sensitive than volume sensitive, metal hydride $\mathrm{H}_{2}$ storage would be the least suitable solution. Ideally, light hydrides would be used, however, they are generally more difficult to re-fuel due to their availability. This leaves Liquid $\mathrm{H}_{2}$ $\left(\mathrm{LH}_{2}\right)$ and high pressure Compressed Gaseous $\mathrm{H}_{2}\left(\mathrm{CGH}_{2}\right)$ as remaining storage options.

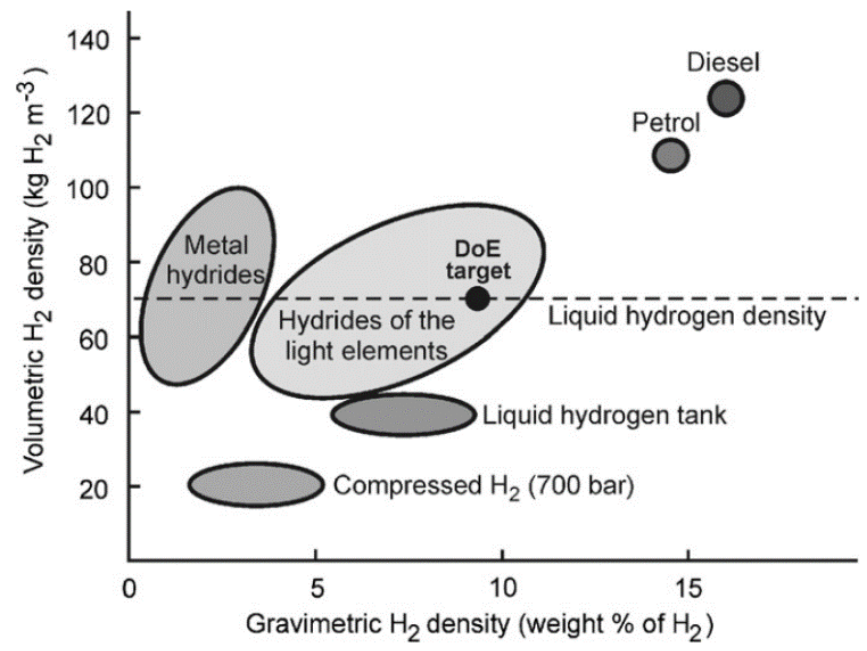

Figure 3. Gravimetric and volumetric densities of various hydrogen storage options. 'DoE target' represents the US Department of Energy target for hydrogen storage material [54].

Although widely available, both $\mathrm{CGH}_{2}$ and $\mathrm{LH}_{2}$ have their inherent disadvantages. For $\mathrm{CGH}_{2}$, the high storage pressures of up to $700 \mathrm{bar}$ [55] required to improve storage efficiencies may not gain public acceptance due to the perceived risk [56]. Whereas, for $\mathrm{LH}_{2}$ the key issue surrounds a phenomenon called 'boil-off" [56-57]. This is caused by the temperature of the gas increasing above its boiling point, for $\mathrm{H}_{2}$ this is $20.3 \mathrm{~K}$. The evolved gas is then released to the atmosphere to avoid over pressurisation. 
High pressure $\mathrm{CGH}_{2}$ is gaining acceptance in the automotive industry, leading to an increase in compatible fuelling infrastructure. To tap in to this growing resource, it would be desirable to use $\mathrm{CGH}_{2}$ in aviation. However, the low storage efficiency compared to $\mathrm{LH}_{2}$ may limit use to smaller short-range aircraft. Commercial data [5862] was used to find a cut-off point between the two storage options by relating the mass of $\mathrm{H}_{2}$ stored to the total mass and volume of the storage system. The results are shown in Figure 4.

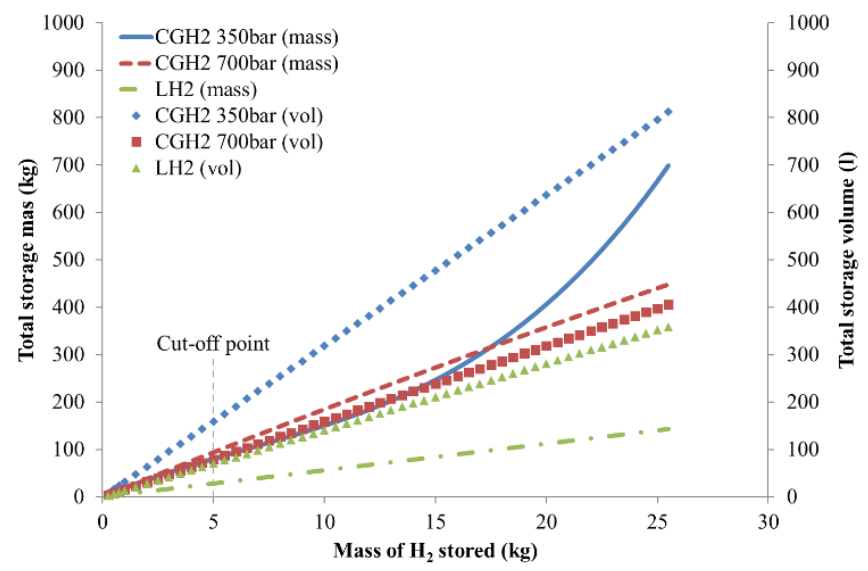

Figure 4. Total $\mathrm{H}_{2}$ storage system mass and volume change with respect to mass of $\mathrm{H}_{2}$ stored with preferred use cut-off point shown

Based on the total mass of the storage system, 350bar $\mathrm{CGH}_{2}$, 700bar $\mathrm{CGH}_{2}$ and $\mathrm{LH}_{2}$ all show similar performance up to $5 \mathrm{~kg}$ of $\mathrm{H}_{2}$ stored. Above this point, both $\mathrm{CGH}_{2}$ options diverge and increase faster than the $\mathrm{LH}_{2}$ storage solution.

Based on the total volume occupied by the storage system, 700bar $\mathrm{CGH}_{2}$ and $\mathrm{LH}_{2}$ show similar performance up to $5 \mathrm{~kg}$ of $\mathrm{H}_{2}$ stored whereas, the 350 bar $\mathrm{CGH}_{2}$ solution occupies a significantly larger volume. Above $5 \mathrm{~kg}$ of $\mathrm{H}_{2}$ stored, the $\mathrm{LH}_{2}$ system always occupies a smaller volume than $700 \mathrm{bar} \mathrm{CGH}_{2}$.

Combining these two relationships gives a cut-off point of $5 \mathrm{~kg}$ of $\mathrm{H}_{2}$ stored. For quantities of $\mathrm{H}_{2}$ less than $5 \mathrm{~kg}, 700$ bar $\mathrm{CGH}_{2}$ should be used due to the larger volume occupied by 350 bar $\mathrm{CGH}_{2}$. Above this point $\mathrm{LH} 2$ should be used due to the significantly higher mass of the $\mathrm{CGH}_{2}$ solutions.

\section{Oxidant}

Oxidant, generally $\mathrm{O}_{2}$ can either be extracted from the ambient air in an air breathing system, or stored on-board in pure form in an air independent system. The main aircraft specific consideration for which system should be used is flight altitude. To investigate the effect of increasing altitude on the operation of an air breathing FC system, the power required to compress the necessary inlet air was calculated over a range of altitudes. The power of a FC suitable compressor can be found from Equation 6 [49].

$P_{\text {comp }}=c_{p} \frac{T_{1}}{\eta_{c}}\left(\left(\frac{P_{2}}{P_{1}}\right)^{\frac{\gamma-1}{\gamma}}-1\right) \dot{m}$

Where,

$\mathrm{P}_{\text {comp }}=$ compressor power $(\mathrm{W})$

$c_{p}=$ specific heat capacity of air $(1004 \mathrm{~J} / \mathrm{kgK}[49])$

Page 5 of 11
$\mathrm{T}_{1}=$ compressor inlet temperature $(\mathrm{K})$

$\eta_{\mathrm{c}}=$ isentropic compressor efficiency $(0.7$ used as a typical value [49])

$\mathrm{P}_{2}=$ compressor exit pressure (FC inlet pressure) (2.0bar [49])

$\mathrm{P}_{1}=$ compressor inlet pressure (bar)

$\gamma=$ ratio of specific heat capacities of air (1.4 [49])

$\dot{m}=$ required air mass flow $(\mathrm{kg} / \mathrm{s})$

The fuel cell model was used to calculate the required air mass flow based on the parameters in Table 6 . This was found to be $0.02 \mathrm{~kg} / \mathrm{s}$.

Table 6. Parameters used to find air mass flow for compressor power variation with altitude investigation

\begin{tabular}{|l|l|}
\hline Parameter & Value \\
\hline FC power & $15 \mathrm{~kW}$ \\
\hline Cathode stoichiometry & 2 \\
\hline Number of cells & 500 \\
\hline Operating current & $50 \mathrm{~A}$ \\
\hline
\end{tabular}

Air pressure and temperature both vary with altitude [63]. Data from the International Standard Atmosphere (ISA) [63] was used to calculate the compressor power requirement for a range of altitudes. The results are shown in Figure 5.

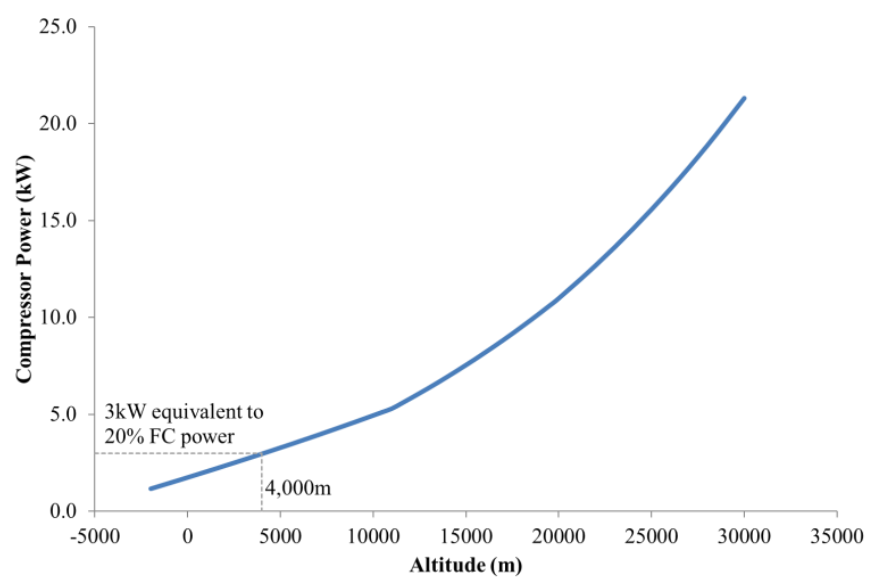

Figure 5. Air density variation with altitude between $5,000 \mathrm{~m}$ below sea-level to $30,000 \mathrm{~m}$ above sea-level [64]

At an altitude of $4,000 \mathrm{~m}(\approx 13,000 \mathrm{ft})$ the power required by the compressor to meet the inlet air mass flow requirement was $20 \%$ of that produced by the FC. This is an excessive parasitic load for an aircraft fuel cell therefore, an air independent system will be required for any aircraft operating at an altitude above $4,000 \mathrm{~m}$. An air breathing design will be used for altitudes less than $4,000 \mathrm{~m}$.

The main component of an air independent system is a method of storing pure $\mathrm{O}_{2}$ on-board the aircraft in a sufficient quantity to meet the desired endurance and cooling requirements. The same methodology was used to find the most suitable $\mathrm{O}_{2}$ storage method as was used for $\mathrm{H}_{2}$ storage using commercial data [58-62, 64-66]. The results are shown in Figure 6. 


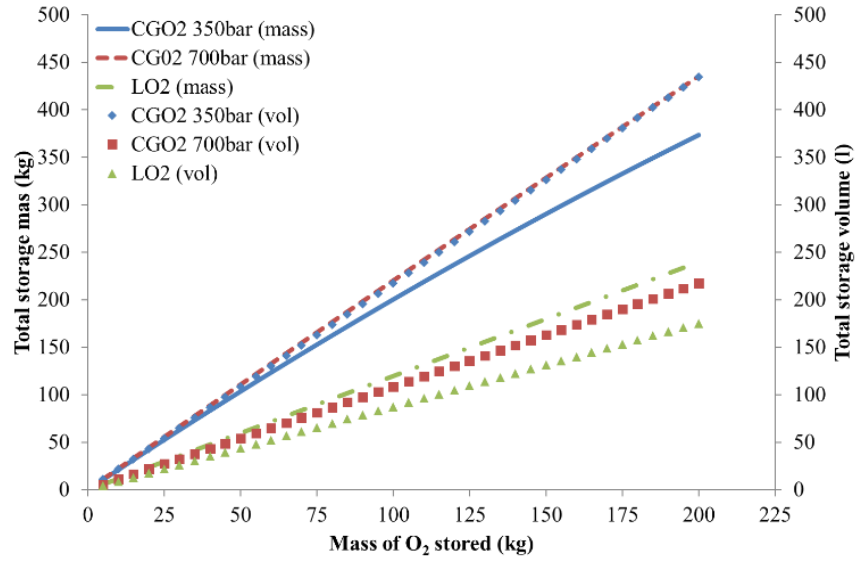

Figure 6. Total $\mathrm{O}_{2}$ storage system mass and volume change with respect to mass of $\mathrm{O}_{2}$ stored

Based on the total mass and volume of the storage systems, $\mathrm{LO}_{2}$ is the only storage solution which shows good performance. Liquid oxygen storage will be used on all aircraft flying at an altitude over $4,000 \mathrm{~m}$.

\section{Combined Model}

Combined fuel cell sizing model is a combination of the aircraft categorisation, fuel cell sizing and balance of plant models detailed previously. The user is given the option of bypassing the aircraft categorisation model if the electrical requirements are known.

The aim of the combined model is to combine user inputs with the previously defined calculations to provide high-level FC data as well as the overall mass and volume of the FC system.

Figure 7 shows the process flow of the combined model. User inputs are shown along with interconnects between the sub-models.

\section{Results and discussion}

\section{Aircraft Categorisation Validation}

Outputs from the aircraft categorisation model were compared with real data for a selection of production aircraft. A range of categories were used for validation as each is based on different relationships. Validation results are shown in Table 7.

The results from the validation show a good correlation between the real and modelled data. Generally, an error of less than 5\% was obtained by the model. Certain instances were higher than this cutoff. This occurs in cases where a category consists of a small data set.

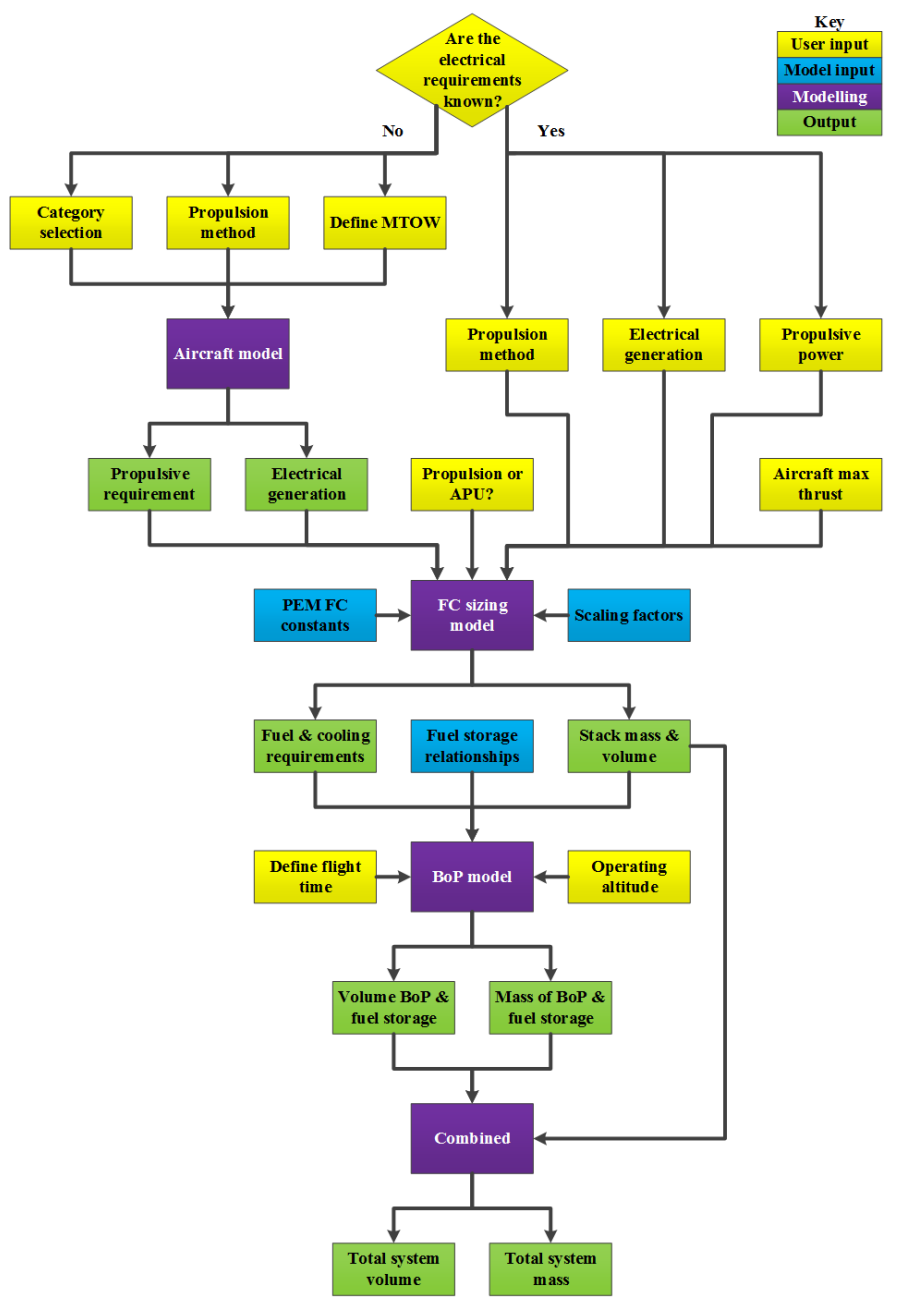

Table 7. Aircraft categorisation model validation

\begin{tabular}{|c|c|c|c|c|c|c|}
\hline \multirow[b]{2}{*}{ Aircraft } & \multicolumn{3}{|c|}{$\begin{array}{l}\text { Propulsive power / max } \\
\text { thrust }\end{array}$} & \multicolumn{3}{|c|}{$\begin{array}{l}\text { Electrical generation } \\
\text { capability }\end{array}$} \\
\hline & Real & Model & Error & Real & Model & Error \\
\hline DLR HY4 & $80 \mathrm{~kW}$ & $80 \mathrm{~kW}$ & $0 \%$ & $45 \mathrm{~kW}$ & $45 \mathrm{~kW}$ & $0 \%$ \\
\hline $\begin{array}{l}\text { Airbus } \\
\text { C212 }\end{array}$ & $1,380 \mathrm{~kW}$ & $1,286 \mathrm{~kW}$ & $7 \%$ & $18 \mathrm{~kW}$ & $19 \mathrm{~kW}$ & $5 \%$ \\
\hline $\begin{array}{l}\text { Lockheed } \\
\text { Martin F- } \\
\text { 35B }\end{array}$ & $191 \mathrm{kN}$ & $197 \mathrm{kN}$ & $3 \%$ & $60 \mathrm{~kW}$ & $60 \mathrm{~kW}$ & $0 \%$ \\
\hline $\begin{array}{l}\text { Airbus } \\
\text { A400M }\end{array}$ & $38,776 \mathrm{~kW}$ & $\begin{array}{l}37,989 \\
\mathrm{~kW}\end{array}$ & $2 \%$ & $225 \mathrm{~kW}$ & $225 \mathrm{~kW}$ & $0 \%$ \\
\hline $\begin{array}{l}\text { Airbus } \\
\text { A330-200 }\end{array}$ & $632 \mathrm{kN}$ & $643 \mathrm{kN}$ & $2 \%$ & $259 \mathrm{~kW}$ & $277 \mathrm{~kW}$ & $7 \%$ \\
\hline $\begin{array}{l}\text { Reims } \\
\text { F406 }\end{array}$ & $746 \mathrm{~kW}$ & $728 \mathrm{~kW}$ & $2 \%$ & $7 \mathrm{~kW}$ & $8 \mathrm{~kW}$ & $11 \%$ \\
\hline $\begin{array}{l}\text { Cirrus } \\
\text { SR22 }\end{array}$ & $231 \mathrm{~kW}$ & $234 \mathrm{~kW}$ & $1 \%$ & $2 \mathrm{~kW}$ & $2 \mathrm{~kW}$ & $0 \%$ \\
\hline
\end{tabular}

Page 6 of 11 
Given the wide range of aircraft types catered for by the model and its function to provide a guide to manufacturers, a $10 \%$ error in the aircraft categorisation model was deemed acceptable. This error will be improved by modifying the relationships with data from more aircraft when it is available.

Overall, the aircraft categorisation model can accurately predict the electrical generation capability and propulsive requirements across the 15 defined aircraft categories.

\section{Combined Model Results}

Results for the combined model were highlighted using two wildly different aircraft as examples. The first example is a small lightweight UAV designed to use a FC as the primary power source for propulsion. This style of aircraft is designed for low altitude operation and could either be autonomous or remotely piloted from the ground. Full input parameters and model outputs are consolidated in Table 8.

Table 8. Input selections and model outputs for a typical small FC powered UAV

\begin{tabular}{|l|l|l|l|l|}
\hline \multicolumn{2}{|c|}{ Input } & \multicolumn{2}{c|}{ Output } \\
\hline Aircraft category & Fuel cell & FC power & $250 \mathrm{~W}$ \\
\hline $\begin{array}{l}\text { Propulsion } \\
\text { method }\end{array}$ & Propeller & Number of cells & 42 \\
\hline $\begin{array}{l}\text { FC for propulsion } \\
\text { or APU? }\end{array}$ & $\begin{array}{l}\text { Propulsive } \\
\text { power }\end{array}$ & Cooling option & Air \\
\hline MTOW & $7 \mathrm{~kg}$ & Cathode inlet & Ambient \\
\hline \multirow{2}{*}{ Endurance } & $5 \mathrm{hrs}$ & & FC stack & $0.83 \mathrm{~kg}$ \\
\cline { 4 - 5 } & & Mass & $\begin{array}{l}\text { Fuel including } \\
\text { storage }\end{array}$ & $2.20 \mathrm{~kg}$ \\
\cline { 4 - 5 } & & & BoP & $0.44 \mathrm{~kg}$ \\
\hline & & & FC stack & 1.33 litres \\
\cline { 4 - 5 } Operating altitude & $100 \mathrm{~m}$ & \multirow{2}{*}{ Volume } & $\begin{array}{l}\text { Fuel including } \\
\text { storage }\end{array}$ & 1.87 litres \\
\cline { 4 - 5 } & & & BoP & 0.06 litres \\
\hline
\end{tabular}

The results for the small FC powered UAV example show that the model correctly predicted an air breathing design based on the low operating altitude of $100 \mathrm{~m}$. Key high-level FC data is also provided in the form of total FC power and the number of cells required in the stack. The total system mass, including all fuel is less than $50 \%$ of the MTOW and provides up to a five-hour flight time.

The total electrical energy used by this system is $1,250 \mathrm{Wh}$ if it is assumed the FC operates at maximum power for the full five hours. A similar capacity battery can be made by using four cells from the 2016 Nissan Leaf, this would have a mass of $8.5 \mathrm{~kg}$ [67]. This represents a $59 \%$ mass saving by using the FC system instead of the battery.

Page 7 of 11
A large civil airliner was used as the second example. In this case, the FC would be used as an APU and required to operate over a shorthaul flight time of six hours. The model input parameters are based on an Airbus A320 [19-21, 24], these are shown in Table 9 along with the model outputs.

Table 9. Input selections and model outputs for an airbus A320

\begin{tabular}{|c|c|c|c|c|}
\hline \multicolumn{2}{|c|}{ Input } & \multicolumn{3}{|c|}{ Output } \\
\hline Aircraft category & $\begin{array}{l}\text { Airliner and } \\
\text { freighter }\end{array}$ & \multicolumn{2}{|c|}{ FC power } & $162 \mathrm{~kW}$ \\
\hline $\begin{array}{l}\text { Propulsion } \\
\text { method }\end{array}$ & Jet & \multicolumn{2}{|c|}{ Number of cells } & 2694 \\
\hline $\begin{array}{l}\text { FC for } \\
\text { propulsion or } \\
\text { APU? }\end{array}$ & APU & \multicolumn{2}{|c|}{ Cooling method } & Liquid \\
\hline MTOW & $73,500 \mathrm{~kg}$ & \multicolumn{2}{|c|}{ Cathode inlet } & $\begin{array}{l}\text { On-board } \\
\mathrm{O}_{2}\end{array}$ \\
\hline \multirow{3}{*}{ Endurance } & \multirow{3}{*}{$6 \mathrm{hrs}$} & \multirow{3}{*}{ Mass } & FC stack & $364.4 \mathrm{~kg}$ \\
\hline & & & $\begin{array}{l}\text { Fuel } \\
\text { including } \\
\text { storage }\end{array}$ & $1,828 \mathrm{~kg}$ \\
\hline & & & $\mathrm{BoP}$ & $244.8 \mathrm{~kg}$ \\
\hline \multirow{3}{*}{$\begin{array}{l}\text { Operating } \\
\text { altitude }\end{array}$} & \multirow{3}{*}{$12,130 \mathrm{~m}$} & \multirow{3}{*}{ Volume } & FC stack & 299.3litres \\
\hline & & & $\begin{array}{l}\text { Fuel } \\
\text { including } \\
\text { storage }\end{array}$ & 1,918litres \\
\hline & & & $\mathrm{BoP}$ & 128.6litres \\
\hline
\end{tabular}

An air independent design is correctly produced by the model as a result of the $12,130 \mathrm{~m}$ operating altitude. The model gives a total FC system mass of $\approx 2,500 \mathrm{~kg}$ including the LC FC stack, on-board $\mathrm{H}_{2}$ and $\mathrm{O}_{2}$ storage and associated $\mathrm{BoP}$. This is more than double the mass of an existing Honeywell 131-9[A] APU which weighs 944kg, including the fuel burnt during six hours of continuous operation assuming an operating efficiency of $25 \%$ [68].

The large mass difference between the FC system and existing system is largely a result of the inefficient storage solutions available for hydrogen and oxygen. A possible alternative would be to use SOFC technology as it is capable of being fuelled by light hydrocarbons which could potentially be stored in a similar manner to current jet fuel. The use of SOFCs in aircraft has been a topic of extensive research $[4,69-70]$ with key conclusions meriting the efficiency of SOFC technology and the potential to use the highquality waste heat.

Even though current PEM FC technology cannot be used to completely replace the APU on large civil airliners, partial substitution of existing electrical generation equipment for fuel cell technology should be considered on a case-by-case basis [14]. 


\section{Conclusions}

Fifteen aircraft categories have been defined based on the aircrafts primary function and propulsion method. A model was then developed which can predict the electrical generation capability and propulsive requirements. Validating the categorisation model against real aircraft data showed a good correlation between the real and modelled data. Generally, an error of less than $5 \%$ was obtained by the model. Certain instances, higher than this cut-off percentage arose when the model was based off a small dataset.

An investigation was carried out into the most suitable storage method for both hydrogen and oxygen as both will be required for certain fuel cell system designs. It was found that if the amount of hydrogen required is less than five kilograms then it should be stored as a compressed gas at 700bar. For amounts of hydrogen above five kilograms, liquid storage should be used. Oxygen should always be stored in liquefied form as it is the most efficient method by both mass and volume.

The fuel cell model was based on current polymer electrolyte membrane technology and can appropriately define key, high-level parameters. By considering the ambient conditions and altitude a congruous cathode fuelling option. This lead to either an air breathing or air independent system design.

Total fuel cell system mass and volume are calculated by the combined model. These could be used by aircraft manufacturers, both military and small civil as a guide in the detailed design phase. For larger aircraft, it was found that current polymer electrolyte membrane fuel cell technology is not able to match the gravimetric power density of existing auxiliary power units. However, partial substitution of existing electrical generation equipment for fuel cell technology should be considered on a case-by-case basis.

\section{References}

1. IATA, "IATA 2015 Report on Alternative Fuels," http://www.iata.org/publications/Documents/2015-reportalternative-fuels.pdf, accessed Mar. 2017.

2. Wang, Y., Chen, K., Mishler, J., Cho, S C. et al., "A Review of Polymer Electrolyte Membrane Fuel Cells: Technology, Applications, and Needs on Fundamental Research," Applied Energy 88(4):981-1007, 2011, doi:10.1016/j.apenergy.2010.09.030

3. Kumar, L. and Jain, S., "Electric Propulsion System for Electric Vehicular Technology: A Review," Renewable and Sustainable Energy Reviews 29(01):924-940, 2014, doi:10.1016/j.rser.2013.09.014.

4. Aguiar, P., Brett, D. and Brandon, N., "Solid Oxide Fuel Cell/Gas Turbine Hybrid System Analysis for High-altitude Long-endurance Aerial Vehicles," International Journal of Hydrogen Energy 33(23):7214-7223, 2008, doi:10.1016/j.ijhydene.2008.09.012.

5. Bradley, T., Moffit, B., Marvis, D. and Parekh, D., "Development and Experimental Characterisation of a Fuel Cell Powered Aircraft," Journal of Power Sources 171(2):793-801, 2007, doi:10.1016/j.jpowsour.2007.06.215.

6. Dudek, M., Tomczyk, P., Wygonik, P., Korkosz, M. et al., "Hybrid Fuel Cell - Battery System as a Main Power Unit for Small Unmanned Aerial Vehicles (UAV)," International Journal of Electrochemical Science 8(6):8442-8463, 2013.
7. Renouard-Vallet, G., Kallo, D., Friedrich, A., Schirmer, J. et al., "Fuel Cells for Aircraft Applications," ECS Transactions 30(1):271-280, 2011, doi:10.1149/1.3562482.

8. Guynn, M., Freh, J. and Olson, E., "Evaluation of a Hydrogen Fuel Cell Powered Blended-wing-body Aircraft Concept for Reduced Noise and Emissions," https://ntrs.nasa.gov/archive/nasa/casi.ntrs.nasa.gov/2004003392 4.pdf, accessed Nov. 2016.

9. Herwerth, C., Chiang, C., Ko, A., Matsuyama, S. et al., "Development of a Small Long Endurance Hybrid PEM Fuel Cell Powered UAV," SAE Technical Paper 2007-01-3930, 2007, doi:10.4271/2007-01-3930.

10. Kim, K., Kim, T., Lee, K. and Kwon, S., "Fuel Cell System with Sodium Borohydride as Hydrogen Source for Unmanned Aerial Vehicles," Journal of Power Sources 196(21):9069-9075, 2011, doi:10.1016/j.jpowsour.2011.01.038.

11. Kim, T. and Kwon, S., "Design and Development of a Fuel CellPowered Small Unmanned Aircraft," International Journal of Hydrogen Energy 37(1):615-622, 2012, doi:10.1016/j.ijhydene.2011.09.051.

12. Lapeña-Rey, N., Mosquera, J., Bataller, E., Ortí, A. et al., "Environmentally Friendly Power Sources for Aerospace Applications," Journal of Power Sources 181(2):353-362, 2008, doi:10.1016/j.jpowsour.2007.11.045.

13. McConnell, V., "Military UAVs Claiming the Skies with Fuel Cell Power," Fuel Cells Bulletin: 12-15, Dec. 2007.

14. Pratt, J., Klebanoff, L., Munoz-Ramos, K., Akhil, A. et al., "Proton exchange Membrane Fuel Cells for Electrical Power Generation On-Board Commercial Airplanes," Applied Energy 101(1):776-796, 2013, doi:10.1016/j.apenergy.2012.08.003.

15. Pratt, J., Brouwer, J. and Samuelsen, G., "Performance of Proton Exchange Membrane Fuel Cell at High-Altitude Conditions," Journal of Propulsion and Power 23(2):437-444, 2012, doi:10.2514/1.20535.

16. Renau, J., Lozano, A., Barroso, J., Miralles, J. et al., "Use of Fuel Cell Stacks to Achieve High Altitudes in Light Unmanned Aerial Vehicles," International Journal of Hydrogen energy 40(42):14573-14583, 2015, doi:10.1016/j.ijhydene.2015.02.071.

17. Roth, B. and Giffin, R., "Fuel Cell Hybrid Propulsion Challenges and Opportunities for Commercial Aviation," presented at $46^{\text {th }}$ AIAA/ASME/SAE/ASEE Joint Propulsion Conference \& Exhibit, USA, July 25-28, 2010.

18. Ward, T. and Jenal, N., "Design and Initial Flight tests of a Hydrogen Fuel Cell Powered Unmanned Air Vehicle (UAV)," ECS Transactions 26(1):433-444, 2010, doi:10.1149/1.3429016.

19. Jackson, P., Gunston, B., Willis, D., Munson, K. et al., "Jane's All the World's Aircraft: Development \& Production 20142015," (IHS, 2014), ISBN:978-0710630933.

20. Jackson, P., Gunston, B., Willis, D., Munson, K. et al., "Jane's All the World's Aircraft: Development \& Production 20152016," (IHS, 2015), ISBN:978-0710631359.

21. Jackson, P., Gunston, B., Willis, D., Munson, K. et al., "Jane's All the World's Aircraft: Development \& Production 20162017," (IHS, 2016), ISBN:978-0710631770.

22. Endres, G., Gething, M., "Jane's Aircraft Recognition Guide," (Collins, 2007), ISBN:978-0007257928.

23. Streetly, M., "Jane's All the World's Aircraft: Unmanned 20152016," (IHS, 2015), ISBN:978-07106313381.

24. Airbus Training, "A320-Electrical," http://www.smartcockpit.com/docs/A320-Electrical.pdf, accessed Mar. 2017.

25. Airbus Training, "A330-Electrical," http://www.smartcockpit.com/docs/A330-Electrical.pdf, accessed Mar. 2017. 
26. Airbus Training, "A340-Electrical," http://www.smartcockpit.com/docs/FCOM_A340-Electrical.pdf, accessed Mar. 2017.

27. General Atomics - Aeronautical Systems Inc., "MQ-9

Reaper/Predator," http://www.gaasi.com/Websites/gaasi/images/products/aircraft_systems/pdf/M Q9\%20Reaper_Predator_B_032515.pdf, accessed Mar. 2017.

28. General Atomics - Aeronautical Systems Inc., "Predator B," http://www.gaasi.com/Websites/gaasi/images/products/aircraft_systems/pdf/Pr edator_B021915.pdf, accessed Mar. 2017.

29. Boeing, "F-15 Strike eagle," http://www.boeing.com/defense/f15-strike-eagle/, accessed Mar. 2017.

30. Tavares, S., "Aerospace Engineering Pocket reference," (Taylor \& Francis, 2015), 278-279, ISBN:978-1498703642.

31. Middleton, M., "Better Exponential Curve Fitting Using Excel," presented at Decision Sciences Institute Annual Meeting 41 ${ }^{\text {st }}$, USA, November 20-23, 2010.

32. Microsoft, "LINEST function," https://support.office.com/enus/article/LINEST-function-84d7d0d9-6e50-4101-977afa7abf772b6d?NS=EXCEL\&Version=16\&SysLcid=1033\&UiL cid=1033\&AppVer=ZXL160\&HelpId=xlmain11.chm60097\&ui =en-US\&rs=en-US\&ad=US, accessed Mar. 2017.

33. Larmine, J. and Dicks, A., "Fuel Cell Systems Explained, First Edition," (John Wiley \& Sons, 2000), ISBN978-0471490261.

34. PubChem Open Chemistry Database, "Hydrogen," https://pubchem.ncbi.nlm.nih.gov/compound/Hydrogen, accessed Mar. 2017.

35. PubChem Open Chemistry Database, "Oxygen," https://pubchem.ncbi.nlm.nih.gov/compound/977\#section=Top, accessed Mar. 2017.Horizon Fuel Cell Technologies, "H-Series Stacks 10W-5kW," http://www.horizonfuelcell.com/h-seriesstacks, accessed Aug. 2016.

36. Horizon Fuel Cell Technologies, "H-500XP Designed for Efficiency,"

http://media.wix.com/ugd/047f54_6ceaa64103e944008c48ae2fa 33a655e.pdf, accessed Aug. 2016.

37. Horizon fuel Cell Technologies, "H-1000XP designed for Efficiency,"

http://media.wix.com/ugd/047f54_d140778984ed4c61a0c5d2fc8 b9df2ab.pdf, accessed Aug. 2016.

38. Horizon Energy Systems, “AEROSTACKS, World's Lightest Fuel Cells for Electric UAVs," https://media.wix.com/ugd/047f54_8483372175ef4e1aa43edbe6 2aaae68e.pdf, accessed Aug. 2016.

39. Hydrogenics, "HyPM-HD Power Modules," http://www.hydrogenics.com/wp-content/uploads/HyPM-HDBrochure.pdf, accessed Aug. 2016.

40. Hydrogenics, HyPM-XR Power Modules," http://www.hydrogenics.com/wp-content/uploads/HyPM-XRBrochure.pdf, accessed Aug. 2016.

41. Intelligent Energy Ltd., "Data Sheet, AC10 Stack," http://www.intelligentenergy.com/uploads/accompanying_files/41556_IE_AC10_datasheet_no_crops.pdf, accessed Dec. 2016.

42. Intelligent energy Ltd., "Data Sheet, AC64 Stack," http://www.intelligentenergy.com/uploads/uploads/Datasheets/41556_ie__ac64_datasheet.pdf, accessed Dec. 2016.

43. Ballard Power systems Inc., "FCgen-1020ACS," http://ballard.com/files/PDF/Backup_Power/1020ACS_v2.pdf, accessed Aug. 2016.

44. Ballard Power Systems Inc., "FCvelocity-9SSL," http://ballard.com/files/PDF/Material_Handling/9SSL.pdf, accessed Aug. 2016.

Page 9 of 11
45. Ballard Power Systems Inc., "FCveloCity-HD," http://ballard.com/files/PDF/Bus/FCvelocity_HD_Family_of_Pr oducts_Low_Res.pdf, accessed Aug. 2016.

46. Pragma Industries, "Fuel Cell Systems for Projects and research Work," http://www.pragma-industries.com/wpcontent/themes/default/images/pdf_products/Brochure_FC_SYS TEMS_ENG.pdf, accessed Aug. 2016.

47. DOE., "Fuel Cell Technologies Office Multi-Year Research, Development, and Demonstration Plan - Fuel Cells," https://energy.gov/sites/prod/files/2016/10/f33/fcto_myrdd_fuel _cells.pdf, accessed Mar. 2017.

48. O'Hayre, R., Cha, S., Colella, W. and Prinz, F., "Fuel Cell Fundamentals, Third Edition," (John Wiley \& Sons, 2016), ISBN:978-1119113805.

49. Larmine, J. and Dicks, A., "Fuel Cell Systems Explained, Second Edition," (John Wiley \& Sons, 2003), ISBN:9780470848579.

50. Barbir, F., "PEM Fuel Cells Theory and Practice," (Elsevier Academic Press, 2005), ISBN:978-0080455419.

51. Sunon, "DR Maglev DC Brushless Fan \& Blower," http://docseurope.electrocomponents.com/webdocs/10f0/0900766b810f0b5 2.pdf, accessed Mar. 2017.

52. ebmpapst, "Automotive brushless DC fans Climate control for commercial vehicles Automotive brushless DC fans," http://docseurope.electrocomponents.com/webdocs/140a/0900766b8140a8 13.pdf, accessed Mar. 2017.

53. ebmpapst, "W4E400A Series," http://docseurope.electrocomponents.com/webdocs/140a/0900766b8140a8 2a.pdf, accessed Mar. 2017.

54. Edwards, P., Kuznetsov, V., David, W. and Brandon, N., "Hydrogen and Fuel cells: Towards a Sustainable Energy Future," Energy Policy 36(12):4356-4362, 2008, doi:10.1016/j.enpol.2008.09.036.

55. Gray, E., "Hydrogen Storage - Status and Prospects," Advances in Applied Ceramics 106(1):25-28, 2007, doi:10.1179/174367607X152380.

56. Schlapbach, L. and Züttel, A., "Hydrogen-Storage Materials for Mobile Applications," Nature 414(1):353-358, 2001, doi:10.1038/35104634.

57. Hirscher, M., "Handbook of Hydrogen Storage: New Materials for Future Energy Storage," (Wiley-VCH, 2010), doi:10.1002/9783527629800.

58. Horizon Fuel Cell Technologies, "Ultra-light Composite Cylinder (E-Series)," http://www.fuelcellstore.com/hydrogenequipment/hydrogen-storage/composite-storage-cylinders/ultralight-composite-storage-cylinder-e-series, accessed Jan. 2017.

59. Luxfer Gas Cylinders, "G-Stor ${ }^{\mathrm{TM}} \mathrm{H} 2$ Hydrogen-Storage Cylinders," http://www.luxfercylinders.com/products/alternativefuel/gstorh2, accessed Jan. 2017.

60. Mahytec, "Hydrogen Storage Solutions," http://www.mahytec.com/en/our-solutions/, accessed Jan. 2017.

61. Steelhead Composites, "Hydrogen Gas Storage," http://steelheadcomposites.com/products/gascylinders/hydrogen/, accessed Jan. 2017.

62. Lapesa, "Horizontal Cryogenic Tanks," www.lapesa.es/descargar.php?f=/sites/default/files/documentos/ gnli_1011.pdf, accessed Jan. 2017.

63. Cavcar., "The International Standard Atmosphere (ISA)," Anadolu University, Turkey 1-7, ISBN:92-9194-004-6.

64. Quantum Fuel Systems, "Q-Lite ${ }^{\mathrm{TM}}$ Advanced CNG Fuel Storage Tanks," http://www.qtww.com/product/q-lite-lightest-cngtanks/, accessed Jan. 2017. 
65. Luxfer Gas Cylinders, "L6X Composite Inflation and Aerospace composite-cylinder, accessed Jan. 2017.

66. Chart Industries, "CAIRE Liquid Oxygen Reservoirs," Oxygen-Systems/Reservoirs, accessed Jan. 2017.

67. EV Battery Center, "Lithium Battery Module LiMn2O4/LiNiO2," accessed Mar. 2017.

68. Honeywell, "APU 131-9(A)," 9A_US.pdf, accessed Mar. 2017.

69. Himansu, A., Freeh, J., Steffen, C., Tornabene, A. et al.,

70. NASA, "Emerging Fuel Cell Developments at NASA for Aircraft Applications," ta-Liang.pdf, accessed Mar. 2017.

\section{Nomenclature}

$\mathrm{c}_{\mathrm{p}}$

$E_{0 H H V}$

F

$\mathrm{H}_{2}$

i

$\mathrm{i}_{0}$

$\mathrm{i}_{\mathrm{n}}$

m

$\dot{m}$

$\dot{m}_{H_{2}}$

$\dot{m}_{O_{2}}$

$M_{H_{2}}$

$M_{O_{2}}$

n

$\mathrm{O}_{2}$

$\mathrm{P}_{1}$

$\mathrm{P}_{2}$

$\mathrm{P}_{\text {comp }}$

$\mathrm{P}_{\text {elec }}$

Page 10 of 11 Cylinders," http://www.luxfercylinders.com/products/16xhttp://www.chartindustries.com/Respiratory-Healthcare/Liquid-

http://evbatterycenter.com/HAC4/index.php?option=com_hikas $\underline{\text { hop \&ctrl=product \&task=show \&cid=211\&name=82ah-nissan- }}$ leaf-battery-module-500wh-4x-cells-82ah\&Itemid=686, http://www51.honeywell.com/aero/common/documents/myaeros pacecatalog-documents/ATR Brochures-documents/131"Hybrid Solid Oxide Fuel Cell / Gas Turbine System Design for High Altitude Long Endurance Aerospace Missions," presented at $4^{\text {th }}$ International ASME Conference on Fuel Cell Science, Engineering and Technology, USA, June 19-21, 2006. https://www.netl.doe.gov/File\%20Library/Events/2003/seca/Ani

$$
\begin{array}{ll}
P_{\mathrm{H}_{2}} & \text { partial pressure of hydrogen }(\mathrm{Pa}) \\
P_{\mathrm{H}_{2} \mathrm{O}} & \text { partial pressure of water in exhaust }(\mathrm{Pa}) \\
P_{\mathrm{O}_{2}} & \text { partial pressure of oxygen }(\mathrm{Pa}) \\
\mathrm{R} & \text { universal gas constant }(8.314 \mathrm{~J} / \mathrm{molK}) \\
\mathrm{R}^{2} & \text { coefficient of determination } \\
\mathrm{T} & \text { operating temperature }(\mathrm{K}) \\
\mathrm{T}_{1} & \text { compressor inlet temperature }(\mathrm{K}) \\
\mathrm{V}_{\mathrm{c}} & \text { average cell voltage }(\mathrm{V})
\end{array}
$$

Greek characters,

$\begin{array}{ll}\alpha & \text { charge transfer coefficient } \\ \gamma & \text { ratio of specific heat capacities of air (1.4) } \\ \eta_{\mathrm{c}} & \text { isentropic compressor efficiency }(0.7) \\ \lambda & \text { stoichiometric ratio } \\ \Omega & \text { ohmic resistance }\left(\Omega \mathrm{cm}^{2}\right)\end{array}$

\section{Contact Information}

Professor Rui Chen

Department of Aeronautical and Automotive Engineering Loughborough University, LE11 3TU

email: r.chen@1boro.ac.uk

\section{Acknowledgments}

Funding from EPSRC CDT in Fuel Cells and their Fuels: EP/L015749/1.

Content reviewed and agreed for public release by BAE Systems.

\section{Author Affiliation}

$\begin{array}{ll}\text { Alex Thirkell } & \begin{array}{l}\text { Loughborough University } \\ \text { Rui Chen }\end{array} \\ \text { Ian Harrington } & \text { BAE Systems }\end{array}$

\section{Abbreviations}

AC

Air-cooled

compressor inlet pressure (bar)

APU

Auxiliary power unit

compressor exit pressure (FC inlet pressure) (bar)

BoP

Balance of plant

$\mathrm{CGH}_{2}$ 
DOE

FC

ISA

LC

$\mathbf{L H}_{2}$
Department of Energy

Fuel cell

International Standard Atmosphere

Liquid-cooled

Liquid hydrogen
MTOW

OEM

PEM

SOFC
Maximum take-off weight

Original equipment manufacturer

Polymer electrolyte membrane

Solid oxide fuel cell

Page 11 of 11 